\title{
BMI1 Gene
}

National Cancer Institute

\section{Source}

National Cancer Institute. BMI1 Gene. NCI Thesaurus. Code C18362.

This gene plays a role in transcriptional regulation and embryonic development. 